\title{
RETHINKING 'TOP-DOWN' AND ‘BOTTOM-UP’ ROLES OF TOP AND MIDDLE MANAGERS IN ORGANIZATIONAL CHANGE: IMPLICATIONS FOR EMPLOYEE SUPPORT
}

\author{
Mariano L. M. Heyden ${ }^{1}$ \\ heyden.mariano@gmail.com \\ Newcastle Business School, Australia \\ University House (Room UNH3.19a) \\ Newcastle, NSW 2300, Australia \\ Phone: +61 (0)2492 16725 \\ Sebastian P. L. Fourné \\ s.fourne@gmail.com \\ Wilfrid Laurier University \\ 75 University Ave. W (LH 4108) \\ Waterloo, ON, Canada \\ Phone: +1-519.884.0710 (x3980) \\ Bastiaan A. S. Koene \\ bkoene@rsm.nl \\ Rotterdam School of Management, Erasmus University \\ Burg. Oudlaan 50 (Room T8-20) \\ 3062PA Rotterdam, Netherlands \\ Phone: +31 (0)10 4081927 \\ Shahzad (Shaz) Ansari \\ s.ansari@jbs.cam.ac.uk \\ Cambridge Judge Business School \\ University of Cambridge \\ Trumpington Street \\ Cambridge CB2 1AG, UK \\ Phone: +44 (0)1223 768128

\section{Renate Werkman} \\ renate.werkman@kantelwerkers.nl \\ Kantelwerkers \\ Commissarislaan 50 \\ 8016 LB Zwolle, Netherlands \\ Phone: +31 (0)6553 74947
}

\footnotetext{
${ }^{1}$ Corresponding author
} 


\title{
RETHINKING 'TOP-DOWN' AND 'BOTTOM-UP' ROLES OF TOP AND MIDDLE MANAGERS IN ORGANIZATIONAL CHANGE: IMPLICATIONS FOR EMPLOYEE SUPPORT
}

\begin{abstract}
In this study we integrate insights from ‘top-down' and 'bottom-up' traditions in organizational change research to explain employees’ varying dispositions towards change. We distinguish between change initiation and change execution roles and identify four possible role configurations in which top managers (TMs) and middle managers (MMs) can feature in organizational change. We contend that (1) either TMs or MMs can play change initiation and/or change execution roles, (2) TMs and MMs have different strengths and limitations for taking on different change roles, (3) the strengths and limitations of TMs and MMs are compounded or attenuated based on the specific configurations of change initiation and change execution roles, and (4) hypothesize employees' dispositions to support change characterized by different TM-MM change role configurations. Our findings based on survey data from 1,795 respondents in 468 organizations undergoing substantive planned change reveal that change initiated by TMs does not engender above-average level of employee support. However, change initiated by MMs engenders above-average level of employee support, and even more so, if TMs handle the execution. Our study sheds light on employees’ inclinations to support change in relation to the different ways in which TMs and MMs can feature in organizational change. We discuss implications for theory and practice.
\end{abstract}

Keywords: change execution, change initiation, employee support, organizational change, middle managers, roles, top managers. 


\section{INTRODUCTION}

Top managers (TMs) and middle managers (MMs) rely on employee support to realize planned organizational change (Coch and French, 1948; Huy, Corley, and Kraatz, 2014). Organizational change entails 'directing (and redirecting) resources according to a policy or plan of action, and possibly also reshaping organizational structures and systems so that they create and address technological opportunities and competitive threats' (Teece, 2012, p. 1398). Fostering employee support is crucial for avoiding costly delays, deviations, or even failures of intended change (Mantere, Schildt, and Sillince, 2012; Niehoff, Enz, and Grover, 1990; Yang, Zhang, and Tsui, 2010). Still, generating support from the workforce remains an elusive target for managers driving organizational change (Van Riel, Berens, and Dijkstra, 2009; Wooldridge and Floyd, 1990). This raises lingering questions about how TMs and MMs can foster employee support through the complementary roles they play in organizational change.

Change initiation and change execution are key roles of TMs and MMs in organizational change (Hales, 1986; Pinto and Prescott, 1990). Change initiation entails the 'spark' for change through activities such as identifying, articulating, and outlining an opportunity for change, formulating the initial business case, emphasizing its urgency, and securing key budgetary and resource commitments. Change execution in turn is about realizing change plans through activities such as day-to-day adjustments, rolling out initiatives, aligning activities with stated objectives, translating overarching goals into periodic milestones, and giving sense and direction to change recipients. Despite the inherent interplay between these change roles, the literature is still divided along ‘top-down' and 'bottom-up' assumptions about 'who does what.'

Change can be conceptualized as ‘top-down' or 'bottom-up' based on the roles played by managers across the hierarchy ${ }^{1}$ (Burgelman, 1983; Raes et al., 2011). Top-down perspectives view TMs as initiators of change (Carpenter, Geletkanycz, and Sanders, 2004), traditionally portraying MMs as reluctant executors (Balogun and Johnson, 2005; Guth and MacMillan, 
1986). In turn, bottom-up perspectives (Wooldridge, Schmid, and Floyd, 2008) emphasize the pivotal role of MMs in initiating change (Burgelman, 1983; Glaser, Stam, and Takeuchi, 2015; Huy, 2001), but assume that TMs are not always receptive to initiatives emanating from below (Day, 1994; Dutton et al., 1997; Friesl and Kwon, 2016; Rouleau, 2005). Although both streams have been illustrative, they have largely developed in parallel and have each reinforced a restricted range of roles that TMs and MMs can play in change with little cross-fertilization. As a result, 'alternative' ways in which TMs and MMs may feature in organizational change remain underexplored (Carpenter et al., 2004; Menz, 2012; Raes et al., 2011)

In this study we integrate TMs' and MMs' role assumptions from top-down and bottomup perspectives in organizational change to explain employees' dispositions towards change. We shed light on how and why it matters who plays what role (i.e., TMs and/or MMs) by hypothesizing how employees' dispositions towards supporting change may vary in relation to four possible TM-MM change role configurations: Change initiated and executed by TMs (H1), change initiated by TMs and executed by MMs (H2), change initiated by MMs and executed by TMs (H3), and change initiated and executed by MMs (H4). Our approach challenges stereotypical assumptions about change roles in top-down and bottom-up thinking on organizational change and encourages a more comprehensive understanding of possible ways TMs and MMs can feature in organizational change. Taking into account the interplaying strengths and limitations of TMs and MMs for taking on different roles in organizational change further elucidates why employees may vary in their receptiveness to change plans.

Our approach allows us to contribute to the literature on organizational change by (1) suggesting that change initiation and execution is not endemic to TMs and MMs respectively, but that both TMs and/or MMs can play change initiation and/or execution roles, (2) recognizing the differing strengths and limitations of TMs and MMs in taking on different roles, (3) theorizing how TMs' and MMs' strengths and limitations may be compounded or attenuated 
through different ways in which TMs and MMs can feature in organizational change, and (4) explaining employees' varying dispositions in relation to different TM-MM change role configurations. As 'successful organizational adaptation is increasingly reliant on generating employee support and enthusiasm for proposed changes’ (Piderit, 2000, p. 783), our approach provides insights into how change characterized by different TM-MM role configurations is received by non-managerial members of the workforce (Fedor, Caldwell, and Herold, 2006; Fenton-O'Creevy, 1998; Rouleau, 2005) and addresses an important component of why some change plans are more effectively realized than others.

\section{CONCEPTUAL BACKGROUND AND HYPOTHESES}

\section{Cross-echelon roles in organizational change}

TMs and MMs are typically expected to be centrally involved in initiating and executing change (Knight and Paroutis, 2016; Pinto and Prescott, 1990). The theoretical origins of topdown approaches to studying organizational change can be traced back to Chandler (1962) who

interpreted change as a TM activity (see also Child, 1972). The associated assumptions have been exemplified in traditions such as Upper Echelons Theory (Hambrick and Mason, 1984), where theoretical emphasis is on the roles of actors at the organization's apex in driving change (Wiersema and Bantel, 1992). These assumptions ascribe unique role expectations to TMs, often entrusted with leading 'turnarounds' (Chen and Hambrick, 2012). However, theorization in this tradition tends to ignore the complementary roles of MMs (Carpenter et al., 2004), even treating MMs as obstacles (Fenton-O'Creevy, 2001), while sometimes scapegoating them for unfavorable outcomes (Balogun, 2003).

In response to the dominance of top-down perspectives, bottom-up interpretations received mainstream acclaim with the work of Kanter (1981) who praised MMs role in challenging the status quo. Burgelman (1983) followed up by documenting how bottom-up initiatives from MMs can form the basis for organization-wide change. Contemporary thinking 
on bottom-up approaches is often captured in what has become known as the Middle Management Perspective (Wooldridge et al., 2008), which advocates and documents the pivotal roles of MMs in driving change from the organization's core (Balogun and Johnson, 2004; Huy, 2002; Wooldridge and Floyd, 1990). Scholars advocating the bottom-up approach, however, often neglect the importance of TMs filtering through competing priorities (Friesl and Kwon, 2016), attending to multiple stakeholders (Agle, Mitchell, and Sonnenfeld, 1999), and contextualizing the paradoxical demands of change (Knight and Paroutis, 2016).

Collectively, top-down and bottom-up interpretations highlight that (1) change ultimately rests on the interplay between both change initiation and change execution roles and (2) change roles are not endemic to either TMs or MMs. Yet, research on organizational change remains divided along stereotypical, and perhaps even errant, assumptions about who does what in organizational change (Hamel and Zanini, 2014, p. 1). Most commonly, the expectation that TMs initiate change and MMs execute is rarely challenged in research and practice on organizational change (Ahearne, Lam, and Kraus, 2014; Kotter, 1995). Yet, these assumptions unnecessarily constrain our overall understanding of change, as top-down models tend to omit the possibility of 'MMs as change initiators' and bottom-up perspectives neglect the complementary potential of 'TMs as change executors.'

MMs as initiators of change. MMs are often presented as impediments to change (Balogun, 2003; Rouleau and Balogun, 2011). However, there is evidence indicating that MMs can, and do, initiate change (e.g., Glaser, Stam, et al., 2015; Huy, 2001; Mantere, 2008). In particular, MMs more directly confront technological and market developments (Fourné, Jansen, and Mom, 2014; Taylor and Helfat, 2009). This intimate exposure motivates them to advance ideas (Dutton and Ashford, 1993) that can lead to rethinking the strategic priorities of their own units (Galunic and Eisenhardt, 2001) and eventually of the whole organization (Burgelman, 1983). By taking the lead in initiating organization-wide change MMs capitalize 
on synergies across units (Taylor and Helfat, 2009) and showcase their willingness and ability to exercise strategic leadership -which can be crucial for career advancement, reputation development, and mobility (Mom, Fourné, and Jansen, 2015; Ren and Guo, 2011).

TMs as executors of change. TMs have also been known to execute change. As TMs have a 'big picture' overview of how different sub-units interlink throughout the organization's value chain, they can interpret performance-feedback from rollout activities holistically and adjust the execution swiftly as information becomes available (Lee and Puranam, 2015). Whereas MMs are often expected to represent sub-unit interests and have more blind spots regarding distant organizational units (Reitzig and Sorenson, 2013; Ren and Guo, 2011), TMs’ formal authority and access to resources and external networks may help legitimize execution by rolling out change from an organizational-wide perspective, reducing fears of unit-specific favoritism (Day, 1994).

Taken together, we propose that change initiation and change execution are co-dependent roles, but not endemic to a particular managerial echelon. Carrying this premise forward, we propose that a useful vantage point to conceptualize change is through the specific configuration of TM and MM change roles (i.e., who initiates and who executes). We contend that TMs and MMs have different strengths and weaknesses for taking on different roles and that these strengths and limitations may be compounded or attenuated based on the specific way in which TMs and MMs feature in organizational change. Ultimately, the specific configuration of these strengths and limitations, by virtue of the specific roles played by TMs and MMs, may influence how change is received by non-managerial members of the workforce (Fedor et al., 2006; Rouleau, 2005).

\section{Employee responses to TM-MM change role configurations}

Employees are not passive recipients of change (Bartunek et al., 2006; Iverson, 1996). Fedor et al. (2006, p. 2) note that 'attitudinal reactions to change are thought to be driven, in 
part, by feelings of uncertainty, loss of control, and fear of failure engendered by the change events (e.g., Ashford, Lee, and Bobko, 1989; Coch and French, 1948; Oreg, 2003).' To counteract these factors and foster support for change, we can expect that employees will tend to be more supportive of change when they have specific information to help reduce uncertainty (Sharma and Good, 2013), feel empowered and in control of their contribution to the bigger picture (Greenberger and Strasser, 1986), and confident in their beliefs about the organization's ability to handle it (Griffin, Neal, and Parker, 2007).

The literature on TMs and MMs (e.g., Upper Echelons Theory; Middle Management Perspective), highlights several differences that may affect the way TMs and MMs influence employee attitudes towards change. Notably, TMs and MMs differ in the informational specificity of their communications, which affects uncertainty experienced by employees (Raes et al., 2011; Taylor and Helfat, 2009); bases of authority through which they 'get things done', which could affect the sense of control experienced by employees (Floyd and Wooldridge, 1997; Westley, 1990); and the nature and frequency of interaction with employees, which can appease or accentuate their fear of failure (Fenton-O'Creevy, 1998; 2001).

Building on the aforementioned, we argue that the strengths and weaknesses of TMs and MMs may be reinforced or counterbalanced depending on the role configuration through which TMs and MMs feature in an organizational change. We proceed to hypothesize how employees’ attitudes towards change may vary based on the net-effects of four different role configurations: Change initiated and executed by TMs (H1), change initiated by TMs and executed by MMs (H2), change initiated by MMs and executed by TMs (H3), and change initiated and executed by MMs (H4).

Change initiated and executed by TMs. Some evidence suggests that centralizing the handling of change at the top, when both change initiation and execution are in the hands of TMs, is associated with lack of engagement and participation from organizational members 
(Connor, 1993), resistance to change (Pardo del Val and Martínez Fuentes, 2003), foot dragging (MacMillan and Guth, 1985), and lack of trust (Lines et al., 2005). Employees perceive TMdriven change initiation as coercive, imposed and autocratic (J.D. Ford, Ford, and D'Amelio, 2008) or even unfair (Kellermanns et al., 2005), accentuating their feelings of powerlessness (Ashforth, 1989). Ahearne et al. (2014, p. 10) note that TMs are seldom fully informed when initiating change. As a consequence, "management might prefer communicating nothing to communicating information that later turns out to be incorrect” (Schweiger and Denisi, 1991, p. 111) and thus may provide employees with less information about the rationale of changes and focus more on the outcomes to be achieved. In doing so, TMs often assume lower levels to be less strategically aware (Armenakis and Harris, 2002) and that '[w]hen followers have little information, they have little reason to act differently from what the leader prescribes' (Bolton, Brunnermeier, and Veldkamp, 2013, p. 514). Thus, TMs may fail to translate the rationale for desired future states in digestible bits that employees can make sense of to reduce uncertainty (Armenakis, Harris, and Mossholder, 1993).

TMs also tend to articulate change plans in broad, sometimes visionary (Hamel and Prahalad, 2005), manner; with less detail and in ways that are aimed at a broad undifferentiated audience or external stakeholders (Vuori and Huy, 2016). The lack of detail due to TM initiation will be compounded by the fact that when TMs execute change, change plans are less likely to be translated into concrete and actionable projects. The lack of detail in rationale and process aspects may further cultivate fear of failure, as employees may not feel sufficiently informed about what change means for their subunit and their personal interests (Armenakis and Harris, 2002). As such, employees may feel that the general organizational benefits overshadow their own concerns for job security, training, and personal development. Thus, personal valence of the change is likely to be low and may contribute to feelings of uncertainty and low confidence 
in their own and organizational ability to successfully realize the change. Thus, as the net-effect we expect that:

HYPOTHESIS 1 (H1): Change initiated and executed by top managers will be negatively related to employee support for change.

Change initiated by TMs and executed by MMs. In this configuration the problems of TMs' initiation in eliciting employee support discussed in the previous hypothesis are expected to be counterbalanced by MMs proximity to the workforce. While TMs elucidate the change in broad, visionary ways, MMs translate these general output-oriented plans into concrete everyday activities that employees can understand (Nonaka, 1988). Due to MM's unique position as a 'linking pins' between TMs and the workforce, they are at the nexus of key knowledge flows (Mom, Van Den Bosch, and Volberda, 2007) and have access to information from both TMs and day-to-day operations (Hutzschenreuter and Kleindienst, 2006; Nonaka, 1994).

Being closer to employees in terms of more frequent interactions, MMs are in a better position to identify and resolve employee concerns and to frame the true implications of executing the change at hand for them (Ellerup Nielsen and Thomsen, 2009). MMs are better equipped to articulate solutions for unforeseen problems and for addressing inconsistencies between the 'ideal' and the 'real' by using more relatable language. Given their position in the organization, MMs translate strategic objectives into operational changes in ways that lead to more positive evaluations of the potential change outcomes and to more active employee support for the change process (Floyd and Wooldridge, 1997). MMs' informational specificity may increase granularity of process milestones and evoke a sense of participation among employees as the changes are discussed. This may elicit more supportive attitudes among employees as they can see appropriateness and feasibility of the change more clearly (Armenakis and Harris, 2002). Thus, we propose that as a net-effect: 
HYPOTHESIS 2 (H2): Change initiated by top managers and executed by middle managers will be positively related to employee support for change.

Change initiated by MMs and executed by TMs. When MMs initiate change they may be better positioned than TMs to create a strong conviction among employees that change is needed and to engender trust in individual and organizational capacities to undertake it (Armenakis et al., 1993). As MMs tend to be more directly affected by change themselves, given that they incur sunk and learning costs, employees may believe that change initiated by MMs must be truly necessary. This may suggest fairness of the change and fairness of how employees will be treated during or after the change (Rodell and Colquitt, 2009). In addition, MMs' knowledge of operations and employee concerns helps in devising fit-for-purpose communication, which can improve clarity in change initiation processes that may be favorably received by employees (Van Riel et al., 2009).

However, MMs may be prone to position bias and favoring their unit's goals over organization-wide goals (Huy, 2011; Reitzig and Maciejovsky, 2014). TMs can counterbalance this possible bias through their organization-wide focus that allows them to translate MMs' change initiatives to fit into organization-wide strategic thrusts (Collier, Fishwick, and Floyd, 2004). Moreover, MMs usually lack the authority or legitimacy to introduce changes organization-wide (Day, 1994). As TMs have a more comprehensive view of the value chain, they can more swiftly react to bottlenecks that occur during implementation. Hence, the involvement of TMs is not only important for the development of a joint comprehensive assessment of an organization's problems, but also for the allocation of adequate supporting resources (Raes et al., 2011). Thus, when TMs execute change initiated by MMs, employees may perceive that the concerns and ideas developed at other levels within the organization are taken seriously by TMs given the upward flow of ideas and TMs' willingness to adopt them (Burgelman, 1984). This perceived participation may increase receptivity to change by 
signaling principal support and sponsorship of the change (Noda and Bower, 1996). Thus, as the net-effect we expect that:

HYPOTHESIS 3 (H3): Change initiated by middle managers and executed by top managers will be positively related to employee support for change.

Change initiated and executed by MMs. The configuration where MMs execute the initiatives they initiated is characterized by high autonomy of those who are closest to employees. Arguably, MMs have a better understanding of employees' perspectives and are better placed to gain their support for change and its integration into work processes (King and Zeithaml, 2001). In fact, employees may expect that if those who are closer to them are driving change and also executing it, employee concerns will be accommodated in the change initiative throughout its realization (Huy, 2002). As such, there is a lower chance of misinterpretation of ideas or confusion arising from translation losses across organizational levels. Consistency in communication will be high and likely trigger favorable attitudes (Beer and Eisenstat, 1996). Also, the messages regarding the change will be easier to understand and relatable because there is less information and power asymmetry between MMs and employees than between TMs and employees (Armenakis and Harris, 2002).

MMs often adopt a process-orientation when executing planned change due to their intra-organizational focus (Reitzig and Sorenson, 2013; Vuori and Huy, 2016). Because of the proximity, employees will feel that they are in a better position to provide input and thus increases their sense of participation, which has been linked to favorable attitudes (Van Dyne and LePine, 1998). MMs as facilitators may be in a better position to absorb what additional information and skills upgrade employees may need to feel empowered and have confidence in their ability to successfully realize the change (Balogun, 2003; Caldwell, Herold, and Fedor, 2004). Initiation by MMs may offer opportunities for proactive involvement in strategy processes for employees (Van Dyne and LePine, 1998), which usually entails positive 
attitudinal responses (Gopinath and Becker, 2000). It is worth noting that despite the favorable response expected, this configuration might make the change somewhat slower from an organizational perspective, and thus the overall effect not as pronounced as when TMs execute the change. However, this moderate pace might be received favorably by employees, as it gives them the opportunity to gradually make sense of the change. Thus, in this role configuration we expect that:

HYPOTHESIS 4 (H4): Change initiated and executed by middle managers will be positively related to employee support for change.

\section{DATA \& METHODS}

\section{Research design and sample}

We collected multi-respondent data from organizations undergoing substantive planned organizational change using networks of three Dutch management training institutes. These organizations had enrolled several of their members as participants in applied change management modules provided through the network of management training institutes. The organizations represented were all in the initial stages of rolling out a change plan of sufficient significance to warrant resources to be committed to upgrading the knowledge, skills, and tools of key organization members at different hierarchical levels (i.e., formal training of personnel was also a component of their change plans). Participants in the module were managers, frontline supervisors, or internal consultants/support staff; thus participants reflected the varied internal stakeholder groups of the organization undergoing change.

At the intake for the course, participants were instructed to fill out one questionnaire themselves and distribute at least five questionnaires among members throughout their organization they considered generally knowledgeable about the change. To preserve anonymity of respondents and to encourage participation, they sent the questionnaires back directly to the training institute (i.e., not via the participant who distributed the questionnaire to 
them). The questionnaires were distributed at the beginning of the module so the training team could diagnose key aspects of the change process, which allowed the training institutes to customize the modules. As such, the respondents had an incentive to distribute the questionnaires to other members of their organizations who would provide balanced views about the change process. This approach allows for obtaining questionnaires filled out before the outcome of the change is known and before participants were exposed to the contents of the course; hence mitigating the chance of recall biases and post-hoc rationalizations by respondents (Groves et al., 2011).

Over 3,200 questionnaires were completed and returned in usable form, corresponding to 602 different organizations (average 5.29/organization; sd 3.75). Inter-rater scores (rwg) for the variables used in the multivariate analyses ranged between .75 and .87 (James, Demaree, and Wolf, 1993). These scores provide us with the confidence of the reliability of the survey, while our research design allowed us we circumvent biases from having single respondents (or only members who were enrolled in the course) as most organizations had multiple participants enrolled and each distributed the questionnaires to a different set of organizational members. To further mitigate unobserved heterogeneity due to changes driven by different motives, we focused on responses that indicated they were undergoing extensive discretionary change (i.e., change processes that can be initiated within the latitude of action of both TMs and MMs; Finkelstein and Hambrick, 1990), excluding for questionnaires from organizations that were undergoing changes such as mergers and acquisitions, crises, or mandated changes due to changes in external regulatory frameworks. This reduced the sample to around 2,000 responses to be included in our subsequent analyses.

\section{Measures and operationalizations}

Our measures are based on two existing questionnaires on organizational change that have been extensively used and validated both for survey feedback in change processes in individual 
organizations and for large-scale survey research on organizational change (Bennebroek Gravenhorst, 2002; Bennebroek Gravenhorst, Werkman, and Boonstra, 2003).

Independent variables. We used two questions to measure who took the initiative for change and who was involved in change execution. Change initiation relates to impetus for change, so who the respondent believes was primarily responsible for triggering the change initiative (i.e., who took the main initiative for the change?). Change execution relates to who the respondent believes is primarily responsible for driving day-to-day choices during the change process (i.e., who is mainly accountable for executing the change?). Respondents could select corresponding actors for both these items from a non-exclusive list that included, top managers, middle managers, staff members, consultants, employees, regulators, boards of directors, and 'other' (which they could then specify; such as 'unions').

Given the theoretical focus of our study, in the final sample we only included cases in which the respondent indicated that s/he perceived the change as being initiated by TMs and/or MMs. To further clean the data, and in line with our theory, we also excluded cases that were not primarily executed by either TMs and/or MMs (e.g., external consultants). We also excluded cases where respondents may have indicated both TMs and MMs as initiators or executors, as this could introduce noise to the data. Although these criteria are strict and reduced the usable sample from the larger dataset, it allowed us to test our hypotheses on the most applicable empirical domain corresponding to our theory based on a specific subset of our dataset. This approach, however, carries with it a note of caution that our findings are not intended to be generalized beyond the scope of these types of changes. Finally, we computed four categories corresponding to the TM-MM role configurations hypothesized. In our final sample analyzed, 47.55\% were initiated and executed by TMs (H1), 28.14\% initiated by TMs and executed by MMs (H2), 3.14\% initiated by MMs and executed by TMs (H3), and 21.18\% 
initiated and executed by MMs (H4). This approach, next to non-systematic missing data that were excluded, further reduced the valid sample to 1,795 observations within 468 organizations.

Dependent variable. Our dependent variable was aimed at measuring the perceived necessity of, and enthusiasm about, the changes and employees' willingness to actively contribute. Support for change was measured based on four items rated on a five-point Likert scale regarding perceived necessity of changes, contribution and pro-activeness of employees, the extent to which employees are willing to effectuate change, and employees' degree of enthusiasm for the change (Bennebroek Gravenhorst et al., 2003). Confirmatory factor analysis showed that these items loaded on a single dimension and average variance extracted was 63.82\% based on a principal component extraction (J.K. Ford, MacCallum, and Tait, 1986). Cronbach's alpha indicated good reliability (.81) and the scale was constructed based on the mean of the items.

Control variables. In the analysis, we controlled for several variables that could influence our dependent variable. First, organizational size in terms of employees (log transformed) could influence the results. Larger organizations tend to have a different organizational structure, more asymmetries of information, and fewer opportunities to interact than smaller organizations and may thus experience change differently (Raes et al., 2011). We also included dummies to control for industry effects as different industries (i.e., business manufacturing, services, utilities and other regulated, and government units and NGOs) require a different sensitivity to environmental demands and endow managers with differing levels of discretion for enacting change (Devos, Buelens, and Bouckenooghe, 2007).

We controlled for the type of change as changes aimed at market improvements versus changes aimed at internal functions could trigger different responses and attitudes from employees. Respondents could select multiple applicable motives for change processes in question. As multiple responses were possible, we distinguished between the scope of 
internally-focused changes (i.e., implementing new technology, improving efficiency, increasing flexibility, restructuring business processes, and cost-cutting) and market-focused changes (i.e., improving innovativeness, competitive positioning, and increasing customerorientation) as these might trigger different responses from employees. The variable was calculated as the sum of items pertaining to each category as indicated by the respondent.

We also included scales that captured goal clarity to capture clarity of, and agreement about, the change goals and the realization of change goals. Four items on a five-point multiitem Likert scale posited, for instance, 'it is clear where the organization is going with the change,' with an average variance extracted $61.25 \%$ on the respective factor and Cronbach's alpha of .79. We included two scales that capture the general leadership style employed (as perceived by the respondent) during the change: directive change management approach to measure the extent to which the change process was being carried out with very little or no involvement of employees; and participative change management approach to measure the extent to which the change process was characterized by space for different opinions and employee input. Three items, each on a five-point Likert scale, posited, for instance, 'employees have little or no say in what happens during the change' and 'there is plenty of room for ideas from employee,' respectively, for directive and participative change approaches. CFA corroborated the factor structure and Cronbach's alphas were .64 and .76 for directive and participative approach, respectively. All multi-item scales were computed based on the mean of the items.

Controlling for response bias. As we are essentially measuring perceptions, we also controlled for several respondent effects that might bias respondent perceptions of the change (Groves et al., 2011). We controlled for whether the respondent was a member of the change reference group (i.e., respondents who were enrolled in the course and whom we viewed as potentially being more 'actively' involved in the change process) through a dummy variable. 
The aim was to mitigate biases caused by respondents who were more actively involved in the change, thus potentially affecting their evaluations based on a goal-expectation logic (Hollenbeck and Klein, 1987). We also controlled for respondents’ perception of expected chance of success for the change as those with low expectations have been shown to be more cynical in their evaluation of change-related variables (Reichers, Wanous, and Austin, 1997). We did so by asking respondents to indicate how they would estimate the percentage chance of success of the change initiative: (1) $0-10 \%$, (2) $11-20 \%$, (3) $21-30 \%$, (4) 31-40\%, (5) $41-50 \%$; (6) $51-60 \%$, (7) $61-70 \%$, (8) 71-80\%, (9) $81-90 \%$, or (10) $91-100 \%$. We further controlled for the consequences for a respondent's position to gauge the extent to which felt their current position would be affected by the change, ranging from $1=$ very negative to $5=$ very positive, as anticipated harm and benefits constitute psychological reasons organizational members may have a priori attitudes supporting or resisting a particular change initiative (Cunningham et al., 2002). Finally, we included respondent age (interval scaled) as perceptions and attitudes towards change have been shown to vary over the course of their working life (Bal et al., 2012).

Common method variance. We adopted two complementary approaches for diagnosing whether common method variance (CMV) was biasing our results (Podsakoff et al., 2003). First, we adopted the classical Harman single factor model to see whether there was a first 'general' factor that explains more than half of the total variance extracted. Factor analysis results indicate that the first factor did not capture the majority of the variance and each factor accounted for at least $62 \%$ of the average variance extracted. Then, using AMOS 17, we adopted the approach advocated by Podsakoff et al. (2003) by modeling an unmeasured latent construct on all items, next to letting them load on their respective theoretical constructs. An unmeasured latent construct did not account for more than $1.89 \%$ of average variance in the latent constructs. Therefore, we conclude that CMV does not appear to be a threat to our interpretations by biasing our results. 


\section{ANALYSIS \& RESULTS}

We analyze our data using Generalized Estimating Equations (GEE) - which is an extension of the Generalized Linear Model that allows for non-independence of observations caused by nesting, clustering, repeated measures, and/or longitudinal observations (Ballinger, 2004; Echambadi, Campbell, and Agarwal, 2006). Recent applications with non-independent observations have attested to its versatility and robustness (Bogaert, Boone, and Van Witteloostuijn, 2012; Paeleman and Vanacker, 2015). We accounted for potentially correlated error terms (i.e., multiple respondents from same organization) by specifying the GEE as a twolevel model with individual observations nested within the organization. We assess the adequacy of our models based on Wald's chi square (Zheng, 2000).

Insert Tables $1 \& 2$ about here

\section{Results}

Table 1 shows the bivariate correlations for the variables considered in this study. As no anomalies were diagnosed from our correlation table, we proceeded to conduct our multivariate analyses in several stages (Table 2). We first estimated a model with control variables only (Model 1), then corresponding models with control variables plus the specific parameter of corresponding to each of our hypotheses, treating the remaining categories collectively as the reference group (Models 2-5). Although this approach is informative, to provide a more robust validation of our model given that the general reference group captures the remaining three role configurations without differentiation, we sought to estimate a model with the categories for the four TM-MM role configurations simultaneously. In order to draw conclusions about the four TM-MM role configurations hypothesized, we estimated the model without an intercept and include all categories (i.e., no reference category) in the model. Excluding the intercept and including all categories is one way of avoiding the 'dummy variable trap' while allowing for simultaneous inclusion of all categories. ${ }^{2}$ Inclusion of all variables in 
the final model did not change the pattern of results displayed in previous stages, and we base our interpretation on this model (Model 6).

For our first hypothesis (H1), we expected that change initiated and executed by TMs would be negatively related to employee support for change. Findings reported in Model 6 in Table 2 indicate a non-significant coefficient $(b=.04)$, thus not providing support for this hypothesis. For H2, we expected a positive relation between change initiated by TMs and executed by MMs, however, although in the predicted direction, this coefficient was not significant $(b=.01)$. We found statistical support for H3, in which we expected that change initiated by MMs and executed by TMs would be positively related to support for change $(b=.59 ; \mathrm{p}<.01)$. Our final hypothesis (H4) was also supported, where we expected a positive relation between change initiated and executed by MMs and employee support for change $(b=.25 ; \mathrm{p}<.001)$

\section{DISCUSSION}

In this study we developed theory to explain how and why different configurations of TM and MM involvement in the initiation and execution of change influences employee support for change. We have advanced a role-configurational approach to propose that although change initiation and execution are integral managerial components in the orchestration of change, both TM and MM can initiate or execute change - albeit with different approaches to how they enact these roles. We have shown that these TM-MM role configurations (i.e., who initiates and who executes) are a useful vantage point for integrating key insights from top-down and bottom-up perspectives on change. Our findings based on survey data from 1,795 respondents in 468 organizations undergoing planned change show that top-down change does not engender aboveaverage level of employee support, regardless of whether the change is executed by TMs or MMs. However, employee support for change is boosted when change is initiated by MMs and executed by either TMs or MMs, with the strongest positive attitudes being evoked when MMs 
take on initiation and TMs take on execution - although this is the rarest configuration observed in our sample. Our theorizing and allied findings have important implications and contributions.

\section{Implications and contributions}

Rethinking managerial change roles. Although people’s roles represent expectations associated with social positions (Fondas and Stewart, 1994; Hales, 1986), and therefore facilitate continuity of behaviors (Biddle, 1986; Floyd and Lane, 2000), they can also be loosely and dynamically structured (Mantere, 2008). Our main findings reveal that change characterized by MMs initiating change tends to receive the highest support among the workforce, especially when change is executed by TMs. This finding implies that TMs and MMs have distinctive strengths and weaknesses that are most valuable in particular roles if they are paired with a suitable complementary role-taker. For instance, capitalizing on MMs strengths for initiating change (e.g., proximity to employees, deep knowledge of core technologies) with the strengths of TMs for contextualization, and for efficient and legitimate allocation and redistribution of resources, seems to engender the strongest support for change from employees.

Our theory and findings accentuate a blurring distinction between 'thinking' and 'doing' often proliferated in scholarship and management education through dichotomized labels like ‘strategy formulation’ versus ‘tactical implementation’ (Hales, 1986; Pinto and Prescott, 1990). Conventional thinking is still dominated by models of change assuming that TMs initiate change and either assume delegation of its execution to MMs (Balogun and Johnson, 2005; Huy et al., 2014; Lüscher and Lewis, 2008) or do not explain how the theorized change comes about (Westley, 1990). We nuance TMs’ and MMs’ differential agency in taking on various change roles (Mantere, 2008). Our findings show that when these roles are enacted in direct contrast with 'traditional' views on TMs' and MMs' roles (Fondas and Stewart, 1994), the likelihood of generating support throughout the organization is the highest. We especially underscore that 
there might be relative pros and cons inherent in the distinctive features of TMs and MMs that need to be theorized for understanding how they enact different change roles. By distinguishing change initiation and execution as conceptually distinct yet dynamic and interplaying roles, arguing that both TMs and MMs can take on either role, and embracing the core strengths and weaknesses of TMs and MMs in enacting these roles, we offer one way of clarifying the debate on how managers across hierarchical levels influence organizational change.

Effectiveness of top-down and bottom-up perspectives. Our theory and findings support the view that change agents can be found at many levels in organizations (Denis, Lamothe, and Langley, 2001; Plowman et al., 2007). Although studies focusing on TMs have made commendable calls for inclusion of MMs (Carpenter et al., 2004; Menz, 2012), even recent efforts embracing these calls by co-theorizing the roles of both TM and MMs tend to assume that change initiation cascades downwards (cf. Heyden, Sidhu, and Volberda, 2015; Knight and Paroutis, 2016; Thomas, Sargent, and Hardy, 2011) with less emphasis on how change may also spring upwards. We have introduced the notion of TM-MM change role configurations as one vantage point for interpreting and consolidating these complementary streams of thought, embracing insights from both. Our findings suggest that there is value in simultaneously theorizing about the different roles of TMs and MMs and acknowledging how their differences can be configured for synergistic advantage, instead of focusing just on TMs or MMs or even blaming each other for being unenthusiastic (MMs) or unwilling to listen (TMs). As a conceptual lens, our role configurational approach resonates with role based approaches to complex organizational phenomena (e.g., Järventie-Thesleff and Tienari, 2016; Matta et al., 2014; Vandenberghe, Bentein, and Panaccio, 2014) and role agency more specifically (Floyd and Lane, 2000; Mantere, 2008), as well as configurational theorizing (Busenbark et al., 2015; Meyer, Tsui, and Hinings, 1993) to develop novel insights towards understanding the role of different managerial echelons in organizational change. 
Our findings also indicate that the most successful configuration is the least common one (MM initiation, TM execution) in our sample. This attests to the inherently counterintuitive nature of implementing this role configuration in practice. Given the high failure rate of change processes (Hickson, Miller, and Wilson, 2003), often attributed to a lack of support and understanding at lower levels (Huy et al., 2014), our study underscores the need to further develop and empirically validate emergent theory on the interplaying and dynamic roles of TMs and MMs in organizational change, understanding the strengths and weaknesses they bring to the table, without being overly constrained by traditional beliefs and expectations about these actors’ roles.

Cultivating employee support for change. Our cross-echelon insights into organizational change are valuable for contemporary organizations given the increasing pressure for change and need for involvement of the whole workforce (Kotter, 2014) amid rising uncertainty and accelerated pace of development in many industries (Teece, 2014). A main focus of our study - eliciting employee support and enthusiasm for change - is a key responsibility for TMs and MMs to realize change plans (Huy, 2002; Huy et al., 2014; Rafferty, Jimmieson, and Armenakis, 2013). Our multi-echelon perspective (i.e., including TMs and MMs and employees) offers insights into how employees respond to 'who does what' in organizational change. As a result, we provide insights into why change may or may not unfold as planned and why some change initiatives may fail (i.e., failing to foster employee support). Our findings provide a platform for further work on examining the contingencies that may shape such cascading effects (Yang et al., 2010). It is surely worthwhile for organizations to mobilize support for change among employees and to motivate them to pursue organization-wide interests. Employees are not resistant to change by default; but they may vary in their responses to roles played by TMs and MMs in organizational change. Overstepping this conceptual hurdle allows us more latitude for understanding how we can better tap into the organization's 
workforce to realize organization-wide change (J.D. Ford et al., 2008; Oreg, 2003; Pardo del Val and Martínez Fuentes, 2003; Piderit, 2000).

Managerial implications. Our theory and results bear important implications for directing the attention of future research on change management. Our managerial implications speak to both TMs and MMs. We find that when change is characterized by traditional views (i.e., change initiated and executed from the top), it has no significant effect on employee support for change. This seems to turn the change premises of traditional top-down perspectives (e.g., lack of employee understanding and engagement) into self-fulfilling prophecies. MMs may feel forced to execute and do strictly what is expected from them. In the face of uncertainty, people often limit their behaviors and attitudes to the confines of their formally prescribed roles (Staw, Sandelands, and Dutton, 1981). As a result, MMs may fail to engage in extra role behaviors necessary to inspire employees. This may translate into a more 'clinical' interpretation of the change process at lower levels and reduce support among employees. This study's results imply that planned organizational change needs to be understood from a multiechelon perspective - leveraging complementarities between TMs and MMs. In contrast to existing research portraying the 'other' group as a barrier (Dutton et al., 1997; Guth and MacMillan, 1986; Huy et al., 2014), we advocate more open-minded approaches to rolling out planned change that turn differences between TMs and MMs into fruitful opportunities.

The good news is that it is possible to mobilize support among employees and to motivate them to pursue organization-wide interests. However, TMs and MMs need to be mindful of their co-dependence, the change roles they embrace, and how they embrace these roles. Failing to embrace this opportunity can impair, deviate, or retard the realization of change plans (Ezzamel, Willmott, and Worthington, 2001; Noble, 1999). Considering our findings, it may be worthwhile to encourage MMs with appropriate rewards for initiating change that eventually could permeate the whole organization (De Clercq, Castañer, and Belausteguigoitia, 
2011). MMs themselves need not be averse to embracing the roles traditionally ascribed to TMs (e.g., initiating change) even if it may seem risky, and invest in learning the associated skills. Such proactive MM behaviors can ideally be paired with a greater involvement of TMs in executing change after change initiation. TMs can help MMs make sense of the initiative at hand from an organizational perspective, and can reframe and selectively stimulate activities during the change process, for instance, through validation or provision of resources (Fourné et al., 2014) and by promoting the development of change platforms to allow MMs to initiate change (Hamel and Zanini, 2014). Organizations can also nurture the requisite skills through targeted management development programs that focus on MMs’ idea selection, framing, and upward communication as well as TMs' execution abilities. The latter include visible role modeling, communication of clear goals, offering detailed guidance and not withholding any uncertainty reducing information, and celebrating small wins along the way.

\section{Future Research Avenues and Limitations}

We offer several promising research avenues towards developing a comprehensive theory of how TMs and MMs combine to drive organizational change. First, our findings beg for further investigation of the performance outcomes resulting from the different role configurations. A fruitful avenue would be to examine and consolidate the micro-processes through which TMs and MMs can actually make different role configurations work. Indeed, research in this area is gaining momentum, albeit in diverse niches. For instance, Vuori and Huy (2016) take an attentional distribution view and show that insufficient communication of relevant (negative) information between TMs and MMs can affect the quality of change efforts. Heyden, Sidhu, et al. (2015) in turn emphasized the role of a shared social and professional identity to achieve behavioral consistency and stimulate extra-role behaviors, while Knight and Paroutis (2016) emphasized development of a shared interpretative context between TMs and MMs to cope with the paradoxical change demands. Tarakci et al. (2014, p. 1065) advance the 
importance of strategic consensus, by concluding that 'the real locus of consensus is at the middle and lower levels', whereas Raes et al. (2011) argued for cognitive flexibility and integrative bargaining between brief episodes of interactions between TMs and MMs. Our study on TM-MM role configurations adds an important conceptual frame that allows us to organize, develop, and critically evaluate this nascent literature along the latent role assumptions that permeate established thinking in this area.

Second, we encourage the need for understanding anteceding factors that may influence why TMs and MMs take on different roles (e.g., underperformance, career aspirations, environmental conditions) as well as how different properties of change (e.g., type of change) moderate the relation between ensuing role configurations and other possible outcomes (e.g., change success, actual employee behaviors). We thus recommend expanding our understanding to how organizational, group, and individual level factors - which can include factors such as formal authority, financial rewards, values (Gentry et al., 2013), personality (Ou et al., 2014), succession (Georgakakis and Ruigrok, 2016), role differentiation (Heyden, Reimer, and Van Doorn, forthcoming), and rules (Simons, 2013) - moderate the relationships between different role configurations and employee support for organizational change. This could reveal complementarities, but also substitution effects and further enrich our understanding of the various pathways to planned organizational change. In addition, enriching our model with deeper insights from leadership styles and leadership behaviors across echelons could also be informative (O'Reilly et al., 2010).

Third, taking a temporal perspective would allow for disentangling the dynamic nature of exchanges between TMs and MMs. This could be related to goal clarity for different units and the organization as a whole and allow for developing a more comprehensive understanding of why some change projects are able to better leverage the allocated resources across business units. We welcome more research on how these actor groups can interact effectively to enable 
adaptability at both the organization and local unit levels (Glaser, Fourné, and Elfring, 2015; Van Doorn et al., 2015). We suggest tracing direct sources of variation in actors' behaviors and empirical assessment over time of the effectiveness of interpersonal and information exchange processes linking TMs and MMs in change initiatives. Such perspectives may inform how TMs and MMs may enact the roles they take on. Future research may uncover what TMs may be able to learn from MMs and vice versa in enacting change roles. This should also be reflected in the (perhaps joint) training and development of these key actors.

Fourth, MMs' change initiation can lead to the convergence of MMs' and organizational goals (Tannenbaum and Massarik, 1950) given that MMs are known to care about their subordinates (Huy, 2002). This creates a fascinating linkage between strategy process research and agency theory in terms of providing a mechanism for aligning interests. This linkage has been ignored so far as agency theorists tend to focus on contracts and compensation as well as external constituents' rather than on internal monitoring and motivation quests (Eisenhardt, 1989; Ross, 1973). Thus, future research could benefit from more in-depth studies about how goals and incentives converge when organizational change emerges at lower levels. This research could explain convergence among organizational, unit-level, and personal goals.

Our study has several limitations. Our empirical investigation is set in the context of firms undergoing substantive planned organizational change. Although we control for the locus of change, future studies could benefit from refining not only the intra-, but also extraorganizational contingencies that may shape the roles of TMs and MMs in organizational change - and that may provide further insights into when top-down and when bottom-up approaches have their limits. Our analyses are based on planned organizational change in Dutch organizations. While these findings may resonate with other European contexts, they may be less relevant in other contexts that could be investigated to reveal whether and how the results vary. The survey was conducted during change processes and therefore the outcomes of the 
change process were measured in terms of expected outcomes instead of actual outcomes. On the upside, this prevents employees from engaging in post-hoc rationalization based on the actual success of a change initiative.

In addition, despite having multiple respondents per organization, which is widely encouraged as a best practice in survey research (e.g., Eddleston, Kellermanns, and Sarathy, 2008), we relied on the judgment of the members of the change reference group to determine who were knowledgeable about the change process in question. As we have established the relevance of different hierarchical levels, future studies could consider a stratified sampling approach to ensure insights are proportionally obtained from predefined expectations about different organizational levels or functions. Future work based on longitudinal research designs can draw on objective indicators to supplement self-reported data for a clearer picture of focal change processes and their consequences. Another avenue to add important boundary conditions to our work on the implications of different role configurations is looking at how different role configurations are moderated by different specific properties of change processes, for instance, by making distinctions between exploratory and exploitative change processes (e.g., Kwee, Van Den Bosch, and Volberda, 2011). The role of environmental moderators could also help refine our baseline theory, as well as expand the theoretical focus beyond TMs and MMs by considering, for instance, the roles of boards (Heyden, Oehmichen, et al., 2015), regulators and competitors (Ansari, Garud, and Kumaraswamy, 2015), and/or external consultants (Heyden et al., 2013) and their approaches to enacting different change roles. We believe all of these are exciting and fruitful areas for further research into how TMs and MMs collectively matter for our understanding of organizational processes of change and their outcomes. 


\section{NOTES}

${ }^{1}$ TMs comprise the managers highest up in the hierarchy (Carpenter et al., 2004), whereas MMs are situated below TMs, but above supervisory levels (Wooldridge et al., 2008).

${ }^{2}$ The most common approach to avoid the 'dummy variable trap' is to drop one of the categories and interpret the marginal effect of the other categories relative to the reference (dropped) category. Another equally viable approach would be to drop the intercept and estimate all the categories in the model (see e.g., Baltagi, 2011; p., 81). The preference is typically based on the more theoretically meaningful interpretation, but should produce the same pattern of results and overall conclusion. As our aim at this stage in the literature is not to say whether one configuration is 'better', but rather highlight that change characterized by each of the four role TM-MM role configurations may have certain strengths and limitations - which in this study we exemplify by showing how it affects employee support for change, we believe that showing all categories in one model (i.e., Model 6 in Table 2) is most intuitive to interpret. This approach is not new and has been used, for instance, by Fombrun and Zajac (1987, p. 41) who note in their study where they test three categories ' ...the use of three dummy variables rather than two dummy variables and an intercept term-presents no problems. As Maddala (1977, p. 34) noted: "If we do not introduce a constant term in the regression equation, we can define a dummy for each group." The typical procedure of dropping one of the dummy variables is simply "more convenient," according to Judge, Hill, Griffiths, Luetkepohl, and Lee (1982: 484).' We thank an anonymous senior editor for encouraging us to clarify this approach. 


\section{REFERENCES}

Agle, B. R., Mitchell, R. K. and Sonnenfeld, J. A. (1999). 'Who matters to ceos? An investigation of stakeholder attributes and salience, corpate performance, and ceo values'. Academy of Management Journal, 42, 507-25.

Ahearne, M., Lam, S. K. and Kraus, F. (2014). 'Performance impact of middle managers' adaptive strategy implementation: The role of social capital'. Strategic Management Journal, 35, 68-87.

Ansari, S. S., Garud, R. and Kumaraswamy, A. (2015). 'The disruptor's dilemma: Tivo and the us television ecosystem'. Strategic Management Journal,

Armenakis, A. A. and Harris, S. G. (2002). 'Crafting a change message to create transformational readiness'. Journal of Organizational Change Management, 15, 169-83.

Armenakis, A. A., Harris, S. G. and Mossholder, K. W. (1993). 'Creating readiness for organizational change'. Human relations, 46, 681-703.

Ashford, S. J., Lee, C. and Bobko, P. (1989). 'Content, cause, and consequences of job insecurity: A theory-based measure and substantive test'. Academy of Management journal, 32, 803-29.

Ashforth, B. E. (1989). 'The experience of powerlessness in organizations'. Organizational behavior and human decision processes, 43, 207-42.

Bal, P. M., De Jong, S. B., Jansen, P. G. and Bakker, A. B. (2012). 'Motivating employees to work beyond retirement: A multi-level study of the role of i-deals and unit climate'. Journal of Management Studies, 49, 306-31.

Ballinger, G. A. (2004). 'Using generalized estimating equations for longitudinal data analysis'. Organizational Research Methods, 7, 127-50.

Balogun, J. (2003). 'From blaming the middle to harnessing its potential: Creating change intermediaries'. British Journal of Management, 14, 69-83.

Balogun, J. and Johnson, G. (2004). 'Organizational restructuring and middle manager sensemaking'. Academy of Management Journal, 47, 523-49.

Balogun, J. and Johnson, G. (2005). 'From intended strategies to unintended outcomes: The impact of change recipient sensemaking'. Organization Studies, 26, 1573-601.

Bartunek, J. M., Rousseau, D. M., Rudolph, J. W. and DePalma, J. A. (2006). 'On the receiving end sensemaking, emotion, and assessments of an organizational change initiated by others'. The Journal of Applied Behavioral Science, 42, 182-206. 
Beer, M. and Eisenstat, R. A. (1996). 'Developing an organization capable of implementing strategy and learning'. Human Relations, 49, 597-619.

Bennebroek Gravenhorst, K. M. (2002). Sterke staaltjes van samenwerking: Survey-feedback voor het aanpakken van belemmeringen bij organisatieverandering. Kluwer.

Bennebroek Gravenhorst, K. M., Werkman, R. A. and Boonstra, J. J. (2003). 'The change capacity of organisations: General assessment and five configurations'. Applied Psychology, 52, 83-105.

Biddle, B. J. (1986). 'Recent development in role theory'. Annual review of sociology, 67-92.

Bogaert, S., Boone, C. and Van Witteloostuijn, A. (2012). 'Social value orientation and climate strength as moderators of the impact of work group cooperative climate on affective commitment'. Journal of Management Studies, 49, 918-44.

Bolton, P., Brunnermeier, M. K. and Veldkamp, L. (2013). 'Leadership, coordination, and corporate culture'. The Review of Economic Studies, 80, 512-37.

Burgelman, R. A. (1983). 'A process model of internal corporate venturing in the diversified major firm'. Administrative Science Quarterly, 223-44.

Burgelman, R. A. (1984). 'Designs for corporate entrepreneurship in established firms'. California Management Review (pre-1986), 26, 154.

Busenbark, J. R., Krause, R., Boivie, S. and Graffin, S. D. (2015). 'Toward a configurational perspective on the ceo a review and synthesis of the management literature'. Journal of Management, 0149206315618448.

Caldwell, S. D., Herold, D. M. and Fedor, D. B. (2004). 'Toward an understanding of the relationships among organizational change, individual differences, and changes in personenvironment fit: A cross-level study'. Journal of Applied Psychology, 89, 868.

Carpenter, M. A., Geletkanycz, M. A. and Sanders, W. G. (2004). 'Upper echelons research revisited: Antecedents, elements, and consequences of top management team composition'. Journal of Management, 30, 749-78.

Chandler, A. D. (1962). 'Strategy and structure: The history of american industrial enterprise'. MIT Press, Cambridge, Mass(1977) The Visible Hand, Harvard University Press, Cambridge, Mass(1980) The Growth of the Transnational Industrial Firm in the United States and the United Kingdom: a Comparative Analysis', Economic History Review, 33, 396-410.

Chen, G. and Hambrick, D. C. (2012). 'Ceo replacement in turnaround situations: Executive (mis) fit and its performance implications'. Organization Science, 23, 225-43. 
Child, J. (1972). 'Organizational structure, environment and performance: The role of strategic choice'. Sociology, 6, 1-22.

Coch, L. and French, J. R. (1948). 'Overcoming resistance to change'. Human relations,

Collier, N., Fishwick, F. and Floyd, S. W. (2004). 'Managerial involvement and perceptions of strategy process'. Long Range Planning, 37, 67-83.

Cunningham, C. E., Woodward, C. A., Shannon, H. S., MacIntosh, J., Lendrum, B., Rosenbloom, D. and Brown, J. (2002). 'Readiness for organizational change: A longitudinal study of workplace, psychological and behavioural correlates'. Journal of Occupational and Organizational Psychology, 75, 377-92.

Day, D. L. (1994). 'Raising radicals: Different processes for championing innovative corporate ventures'. Organization Science, 5, 148-72.

De Clercq, D., Castañer, X. and Belausteguigoitia, I. (2011). 'Entrepreneurial initiative selling within organizations: Towards a more comprehensive motivational framework'. Journal of Management Studies, 48, 1269-90.

Denis, J.-L., Lamothe, L. and Langley, A. (2001). 'The dynamics of collective leadership and strategic change in pluralistic organizations'. Academy of Management Journal, 44, 809-37.

Devos, G., Buelens, M. and Bouckenooghe, D. (2007). 'Contribution of content, context, and process to understanding openness to organizational change: Two experimental simulation studies'. The Journal of social psychology, 147, 607-30.

Dutton, J. E. and Ashford, S. J. (1993). 'Selling issues to top management'. Academy of management review, 18, 397-428.

Dutton, J. E., Ashford, S. J., O'neill, R. M., Hayes, E. and Wierba, E. E. (1997). 'Reading the wind: How middle managers assess the context for selling issues to top managers'.

Echambadi, R., Campbell, B. and Agarwal, R. (2006). 'Encouraging best practice in quantitative management research: An incomplete list of opportunities*'. Journal of Management Studies, 43, 1801-20.

Eddleston, K. A., Kellermanns, F. W. and Sarathy, R. (2008). 'Resource configuration in family firms: Linking resources, strategic planning and technological opportunities to performance'. Journal of Management Studies, 45, 26-50.

Eisenhardt, K. M. (1989). 'Agency theory: An assessment and review'. Academy of management review, 14, 57-74.

Ellerup Nielsen, A. and Thomsen, C. (2009). 'Csr communication in small and medium-sized enterprises: A study of the attitudes and beliefs of middle managers'. Corporate Communications: An International Journal, 14, 176-89. 
Ezzamel, M., Willmott, H. and Worthington, F. (2001). 'Power, control and resistance in 'the factory that time forgot’'. Journal of Management Studies, 38, 1053-79.

Fedor, D. B., Caldwell, S. and Herold, D. M. (2006). 'The effects of organizational changes on employee commitment: A multilevel investigation'. Personnel Psychology, 59, 1-29.

Fenton-O'Creevy, M. (1998). 'Employee involvement and the middle manager: Evidence from a survey of organizations'. Journal of Organizational Behavior, 19, 67-84.

Fenton-O'Creevy, M. (2001). 'Employee involvement and the middle manager: Saboteur or scapegoat?'. Human Resource Management Journal, 11, 24-40.

Finkelstein, S. and Hambrick, D. C. (1990). 'Top-management-team tenure and organizational outcomes: The moderating role of managerial discretion'. Administrative science quarterly, 484-503.

Floyd, S. W. and Lane, P. J. (2000). 'Strategizing throughout the organization: Managing role conflict in strategic renewal'. Academy of management review, 25, 154-77.

Floyd, S. W. and Wooldridge, B. (1997). 'Middle management's strategic influence and organizational performance'. Journal of Management Studies, 34, 465-85.

Fombrun, C. J. and Zajac, E. J. (1987). 'Structural and perceptual influences on intraindustry stratification'. Academy of Management Journal, 30, 33-50.

Fondas, N. and Stewart, R. (1994). 'Enactment in managerial jobs: A role analysis*'. Journal of Management Studies, 31, 83-103.

Ford, J. D., Ford, L. W. and D'Amelio, A. (2008). 'Resistance to change: The rest of the story'. Academy of Management Review, 33, 362-77.

Ford, J. K., MacCallum, R. C. and Tait, M. (1986). 'The application of exploratory factor analysis in applied psychology: A critical review and analysis'. Personnel Psychology,

Fourné, S. P., Jansen, J. J. and Mom, T. J. (2014). 'Strategic agility in mnes:: Managing tensions to capture opportunities across emerging and established markets'. California management review, 56, 13-28.

Friesl, M. and Kwon, W. (2016). 'The strategic importance of top management resistance: Extending alfred d. Chandler'. Strategic Organization, 10.1177/1476127016665253

Galunic, D. C. and Eisenhardt, K. M. (2001). 'Architectural innovation and modular corporate forms'. Academy of Management journal, 44, 1229-49.

Gentry, W. A., Cullen, K. L., Sosik, J. J., Chun, J. U., Leupold, C. R. and Tonidandel, S. (2013). 'Integrity's place among the character strengths of middle-level managers and top-level executives'. The Leadership Quarterly, 24, 395-404. 
Georgakakis, D. and Ruigrok, W. (2016). 'Ceo succession origin and firm performance: A multilevel study'. Journal of Management Studies,

Glaser, L., Fourné, S. L. and Elfring, T. (2015). 'Achieving strategic renewal: The multi-level influences of top and middle managers’ boundary-spanning'. Small Business Economics, 10.1007/s11187-015-9633-51-23.

Glaser, L., Stam, W. and Takeuchi, R. (2015). 'Managing the risks of proactivity: A multilevel study of initiative and performance in the middle management context'. Academy of Management Journal, amj. 2014.0177.

Gopinath, C. and Becker, T. E. (2000). 'Communication, procedural justice, and employee attitudes: Relationships under conditions of divestiture'. Journal of Management, 26, 63-83.

Greenberger, D. B. and Strasser, S. (1986). 'Development and application of a model of personal control in organizations'. Academy of Management Review, 11, 164-77.

Griffin, M. A., Neal, A. and Parker, S. K. (2007). 'A new model of work role performance: Positive behavior in uncertain and interdependent contexts'. Academy of Management Journal, 50, 327-47.

Groves, R. M., Fowler Jr, F. J., Couper, M. P., Lepkowski, J. M., Singer, E. and Tourangeau, R. (2011). Survey methodology. John Wiley \& Sons.

Guth, W. D. and MacMillan, I. C. (1986). 'Strategy implementation versus middle management self-interest'. Strategic Management Journal, 7, 313-27.

Hales, C. P. (1986). 'What do managers do? A critical review of the evidence'. Journal of Management studies, 23, 88-115.

Hambrick, D. C. and Mason, P. A. (1984). 'Upper echelons: The organization as a reflection of its top managers'. Academy of management review, 9, 193-206.

Hamel, G. and Prahalad, C. K. (2005). 'Strategic intent'. Harvard Business Review, 83, 148-61.

Hamel, G. and Zanini, M. (2014). 'Build a change platform, not a change program'. McKinsey \& Company,

Heyden, M. L., Oehmichen, J., Nichting, S. and Volberda, H. W. (2015). 'Board background heterogeneity and exploration-exploitation: The role of the institutionally adopted board model'. Global Strategy Journal, 5, 154-76.

Heyden, M. L., Reimer, M. and Van Doorn, S. (forthcoming). 'Innovating beyond the horizon: Ceo career horizon, top management composition, and r\&d intensity'. Human Resource Management, DOI: 10.1002/hrm.217301-20. 
Heyden, M. L., Sidhu, J. S. and Volberda, H. W. (2015). 'The conjoint influence of top and middle management characteristics on management innovation'. Journal of Management, 0149206315614373.

Heyden, M. L., Van Doorn, S., Reimer, M., Van Den Bosch, F. A. and Volberda, H. W. (2013). 'Perceived environmental dynamism, relative competitive performance, and top management team heterogeneity: Examining correlates of upper echelons' advice-seeking'. Organization Studies, 34, 1327-56.

Hickson, D. J., Miller, S. J. and Wilson, D. C. (2003). 'Planned or prioritized? Two options in managing the implementation of strategic decisions*'. Journal of Management Studies, 40, 1803-36.

Hollenbeck, J. R. and Klein, H. J. (1987). 'Goal commitment and the goal-setting process: Problems, prospects, and proposals for future research'. Journal of applied psychology, $\mathbf{7 2}$, 212.

Hutzschenreuter, T. and Kleindienst, I. (2006). 'Strategy-process research: What have we learned and what is still to be explored'. Journal of Management, 32, 673-720.

Huy, Q. N. (2001). 'In praise of middle managers'. Harvard business review, 79, 72-9, 160.

Huy, Q. N. (2002). 'Emotional balancing of organizational continuity and radical change: The contribution of middle managers'. Administrative Science Quarterly, 47, 31-69.

Huy, Q. N. (2011). 'How middle managers' group-focus emotions and social identities influence strategy implementation'. Strategic Management Journal, 32, 1387-410.

Huy, Q. N., Corley, K. G. and Kraatz, M. S. (2014). 'From support to mutiny: Shifting legitimacy judgments and emotional reactions impacting the implementation of radical change'. Academy of Management Journal, 57, 1650-80.

Iverson, R. D. (1996). 'Employee acceptance of organizational change: The role of organizational commitment'. International Journal of Human Resource Management, 7, 122-49.

James, L. R., Demaree, R. G. and Wolf, G. (1993). 'R wg: An assessment of within-group interrater agreement'. Journal of applied psychology, 78, 306.

Järventie-Thesleff, R. and Tienari, J. (2016). 'Roles as mediators in identity work'. Organization Studies, 37, 237-65.

Judge, G. G., Hill, R. C., Griffiths, W., Luetkepohl, H. and Lee, T. C. (1982). 'Introduction to the theory and practice of econometrics'.

Kanter, R. M. (1981). 'The middle manager as innovator'. Harvard business review, 60, 95-105. 
Kellermanns, F. W., Walter, J., Lechner, C. and Floyd, S. W. (2005). 'The lack of consensus about strategic consensus: Advancing theory and research'. Journal of Management, 31, 71937.

King, A. W. and Zeithaml, C. P. (2001). 'Competencies and firm performance: Examining the causal ambiguity paradox'. Strategic Management Journal, 22, 75-99.

Knight, E. and Paroutis, S. (2016). 'Becoming salient: The tmt leader's role in shaping the interpretive context of paradoxical tensions'. Organization Studies, $10.1177 / 0170840616640844$

Kotter, J. P. (1995). 'Leading change: Why transformation efforts fail'. Harvard business review, 73, 59-67.

Kotter, J. P. (2014). Accelerate: Building strategic agility for a faster-moving world. Harvard Business Review Press.

Kwee, Z., Van Den Bosch, F. A. and Volberda, H. W. (2011). 'The influence of top management team's corporate governance orientation on strategic renewal trajectories: A longitudinal analysis of royal dutch shell plc, 1907-2004'. Journal of Management Studies, 48, 984-1014.

Lee, E. and Puranam, P. (2015). 'The implementation imperative: Why one should implement even imperfect strategies perfectly'. Strategic Management Journal, 10.1002/smj.2414n/an/a.

Lines, R., Selart, M., Espedal, B. and Johansen, S. T. (2005). 'The production of trust during organizational change'. Journal of Change Management, 5, 221-45.

Lüscher, L. S. and Lewis, M. W. (2008). 'Organizational change and managerial sensemaking: Working through paradox'. Academy of Management Journal, 51, 221-40.

MacMillan, I. C. and Guth, W. D. (1985). 'Strategy implementation and middle management coalitions'. Advances in Strategic Management, 3, 233-54.

Mantere, S. (2008). 'Role expectations and middle manager strategic agency'. Journal of Management Studies, 45, 294-316.

Mantere, S., Schildt, H. A. and Sillince, J. A. (2012). 'Reversal of strategic change'. Academy of Management Journal, 55, 172-96.

Matta, F. K., Scott, B., Koopman, J. and Conlon, D. (2014). 'Does seeing" eye to eye" affect work engagement and ocb? A role theory perspective on $\operatorname{lmx}$ agreement'. Academy of Management Journal, amj. 2014.0106.

Menz, M. (2012). 'Functional top management team members a review, synthesis, and research agenda'. Journal of Management, 38, 45-80. 
Meyer, A. D., Tsui, A. S. and Hinings, C. R. (1993). 'Configurational approaches to organizational analysis'. Academy of Management Journal, 36, 1175-95.

Mom, T. J., Fourné, S. P. and Jansen, J. J. (2015). 'Managers’ work experience, ambidexterity, and performance: The contingency role of the work context'. Human Resource Management,

Mom, T. J., Van Den Bosch, F. A. and Volberda, H. W. (2007). 'Investigating managers' exploration and exploitation activities: The influence of top-down, bottom-up, and horizontal knowledge inflows*'. Journal of Management Studies, 44, 910-31.

Niehoff, B. P., Enz, C. A. and Grover, R. A. (1990). 'The impact of top-management actions on employee attitudes and perceptions'. Group \& Organization Management, 15, 337-52.

Noble, C. H. (1999). 'The eclectic roots of strategy implementation research'. Journal of business research, $45,119-34$.

Noda, T. and Bower, J. L. (1996). 'Strategy making as iterated processes of resource allocation'. Strategic Management Journal, 17, 159-92.

Nonaka, I. (1988). 'Toward middle-up-down management: Accelerating information creation'. Sloan management review, 29, 9-18.

Nonaka, I. (1994). 'A dynamic theory of organizational knowledge creation'. Organization science, $5,14-37$.

O'Reilly, C. A., Caldwell, D. F., Chatman, J. A., Lapiz, M. and Self, W. (2010). 'How leadership matters: The effects of leaders' alignment on strategy implementation'. The Leadership Quarterly, 21, 104-13.

Oreg, S. (2003). 'Resistance to change: Developing an individual differences measure'. Journal of applied Psychology, 88, 680.

Ou, A. Y., Tsui, A. S., Kinicki, A. J., Waldman, D. A., Xiao, Z. and Song, L. J. (2014). 'Humble chief executive officers' connections to top management team integration and middle managers’ responses'. Administrative Science Quarterly, 59, 34-72.

Paeleman, I. and Vanacker, T. (2015). 'Less is more, or not? On the interplay between bundles of slack resources, firm performance and firm survival'. Journal of Management Studies,

Pardo del Val, M. and Martínez Fuentes, C. (2003). 'Resistance to change: A literature review and empirical study'. Management Decision, 41, 148-55.

Piderit, S. K. (2000). 'Rethinking resistance and recognizing ambivalence: A multidimensional view of attitudes toward an organizational change'. Academy of management review, 25, 783-94.

Pinto, J. K. and Prescott, J. E. (1990). 'Planning and tactical factors in the project implementation process'. Journal of Management studies, 27, 305-27. 
Plowman, D. A., Baker, L. T., Beck, T. E., Kulkarni, M., Solansky, S. T. and Travis, D. V. (2007). 'Radical change accidentally: The emergence and amplification of small change'. Academy of Management Journal, 50, 515-43.

Podsakoff, P. M., MacKenzie, S. B., Lee, J.-Y. and Podsakoff, N. P. (2003). 'Common method biases in behavioral research: A critical review of the literature and recommended remedies'. Journal of applied psychology, 88, 879.

Raes, A. M., Heijltjes, M. G., Glunk, U. and Roe, R. A. (2011). 'The interface of the top management team and middle managers: A process model'. Academy of management review, 36, $102-26$.

Rafferty, A. E., Jimmieson, N. L. and Armenakis, A. A. (2013). 'Change readiness a multilevel review'. Journal of Management, 39, 110-35.

Reichers, A. E., Wanous, J. P. and Austin, J. T. (1997). 'Understanding and managing cynicism about organizational change'. The Academy of Management Executive, 11, 48-59.

Reitzig, M. and Maciejovsky, B. (2014). 'Corporate hierarchy and vertical information flow inside the firm—a behavioral view'. Strategic Management Journal, 10.1002/smj.2334n/a$\mathrm{n} / \mathrm{a}$.

Reitzig, M. and Sorenson, O. (2013). 'Biases in the selection stage of bottom-up strategy formulation'. Strategic Management Journal, 34, 782-99.

Ren, C. R. and Guo, C. (2011). 'Middle managers'strategic role in the corporate entrepreneurial process: Attention-based effects'. Journal of Management, 0149206310397769.

Rodell, J. B. and Colquitt, J. A. (2009). 'Looking ahead in times of uncertainty: The role of anticipatory justice in an organizational change context'. Journal of applied psychology, 94, 989.

Ross, S. A. (1973). 'The economic theory of agency: The principal's problem'. The American Economic Review, 134-39.

Rouleau, L. (2005). 'Micro-practices of strategic sensemaking and sensegiving: How middle managers interpret and sell change every day*'. Journal of Management Studies, 42, 141341.

Rouleau, L. and Balogun, J. (2011). 'Middle managers, strategic sensemaking, and discursive competence'. Journal of Management Studies, 48, 953-83.

Schweiger, D. M. and Denisi, A. S. (1991). 'Communication with employees following a merger: A longitudinal field experiment'. Academy of Management Journal, 34, 110-35.

Sharma, G. and Good, D. (2013). 'The work of middle managers sensemaking and sensegiving for creating positive social change'. The Journal of Applied Behavioral Science, 49, 95-122. 
Simons, R. (2013). Levers of control: How managers use innovative control systems to drive strategic renewal. Harvard Business Press.

Staw, B. M., Sandelands, L. E. and Dutton, J. E. (1981). 'Threat rigidity effects in organizational behavior: A multilevel analysis'. Administrative Science Quarterly, 501-24.

Tannenbaum, R. and Massarik, F. (1950). 'Participation by subordinates in the managerial decision-making process'. Canadian Journal of Economics and Political Science/Revue canadienne de economiques et science politique, 16, 408-18.

Tarakci, M., Ates, N. Y., Porck, J. P., van Knippenberg, D., Groenen, P. J. and de Haas, M. (2014). 'Strategic consensus mapping: A new method for testing and visualizing strategic consensus within and between teams'. Strategic Management Journal, 35, 1053-69.

Taylor, A. and Helfat, C. E. (2009). 'Organizational linkages for surviving technological change: Complementary assets, middle management, and ambidexterity'. Organization Science, 20, 718-39.

Teece, D. J. (2012). 'Dynamic capabilities: Routines versus entrepreneurial action'. Journal of Management Studies, 49, 1395-401.

Teece, D. J. (2014). 'The foundations of enterprise performance: Dynamic and ordinary capabilities in an (economic) theory of firms'. The Academy of Management Perspectives, 28, 328-52.

Thomas, R., Sargent, L. D. and Hardy, C. (2011). 'Managing organizational change: Negotiating meaning and power-resistance relations'. Organization Science, 22, 22-41.

Van Doorn, S., Heyden, M., Tröster, C. and Volberda, H. (2015). 'Entrepreneurial orientation and performance: Investigating local requirements for entrepreneurial decision-making'. Cognition and Strategy (Advances in Strategic Management, Volume 32) Emerald Group Publishing Limited, 32, 211-39.

Van Dyne, L. and LePine, J. A. (1998). 'Helping and voice extra-role behaviors: Evidence of construct and predictive validity'. Academy of Management Journal, 41, 108-19.

Van Riel, C. B. M., Berens, G. and Dijkstra, M. (2009). 'Stimulating strategically aligned behaviour among employees'. Journal of Management Studies, 46, 1197-226.

Vandenberghe, C., Bentein, K. and Panaccio, A. (2014). 'Affective commitment to organizations and supervisors and turnover a role theory perspective'. Journal of Management, 0149206314559779.

Vuori, T. O. and Huy, Q. N. (2016). 'Distributed attention and shared emotions in the innovation process: How nokia lost the smartphone battle'. Administrative Science Quarterly, 61, 9-51. 
Westley, F. R. (1990). 'Middle managers and strategy: Microdynamics of inclusion'. Strategic Management Journal, 11, 337-51.

Wiersema, M. F. and Bantel, K. A. (1992). 'Top management team demography and corporate strategic change'. Academy of Management Journal, 35, 91-121.

Wooldridge, B. and Floyd, S. W. (1990). 'The strategy process, middle management involvement, and organizational performance'. Strategic Management Journal, 11, 231-41.

Wooldridge, B., Schmid, T. and Floyd, S. W. (2008). 'The middle management perspective on strategy process: Contributions, synthesis, and future research'. Journal of Management, 34, $1190-221$.

Yang, J., Zhang, Z. X. and Tsui, A. S. (2010). 'Middle manager leadership and frontline employee performance: Bypass, cascading, and moderating effects'. Journal of Management Studies, 47, 654-78.

Zheng, B. (2000). 'Summarizing the goodness of fit of generalized linear models for longitudinal data'. Statistics in medicine, 19, 1265-75. 


\section{APPENDIX}

Table 1: Correlations ${ }^{\mathrm{a}}$

\begin{tabular}{|c|c|c|c|c|c|c|c|c|c|c|c|c|c|c|c|c|c|c|c|}
\hline & & (1) & $(2)$ & (3) & (4) & (5) & (6) & (7) & (8) & (9) & $(10)$ & $(11)$ & $(12)$ & $(13)$ & $(14)$ & $(15)$ & $(16)$ & $(17)$ & $(18)$ \\
\hline (1) & Employee Support for Change & & & & & & & & & & & & & & & & & & \\
\hline (2) & CI TM - CE TM & -0.08 & & & & & & & & & & & & & & & & & \\
\hline (3) & CI TM - CE MM & 0.01 & -0.08 & & & & & & & & & & & & & & & & \\
\hline$(4)$ & CI MM - CE TM & 0.02 & -0.03 & -0.01 & & & & & & & & & & & & & & & \\
\hline$(5)$ & CI MM - CE MM & 0.08 & -0.09 & -0.03 & -0.01 & & & & & & & & & & & & & & \\
\hline$(6)$ & Market-Focused Change & 0.09 & 0.04 & 0.02 & -0.04 & 0.01 & & & & & & & & & & & & & \\
\hline (8) & Respondent Age & 0.03 & 0.00 & 0.04 & 0.00 & 0.01 & 0.03 & 0.08 & & & & & & & & & & & \\
\hline (9) & Goal Clarity & 0.40 & 0.00 & 0.05 & 0.00 & 0.06 & 0.05 & 0.08 & 0.10 & & & & & & & & & & \\
\hline$(10)$ & Directive Change Approach & -0.35 & 0.05 & -0.01 & -0.01 & -0.12 & -0.07 & 0.06 & -0.04 & -0.30 & & & & & & & & & \\
\hline$(11)$ & Participative Change Approach & 0.43 & -0.07 & 0.03 & 0.00 & 0.10 & 0.09 & 0.00 & 0.07 & 0.39 & -0.62 & & & & & & & & \\
\hline$(12)$ & Organization Size & -0.10 & -0.06 & -0.02 & 0.01 & -0.07 & 0.02 & 0.14 & 0.00 & 0.00 & 0.17 & -0.20 & & & & & & & \\
\hline (13) & Consequences for Respondent & 0.04 & -0.07 & -0.02 & -0.03 & -0.04 & 0.03 & 0.02 & -0.06 & -0.03 & 0.05 & -0.06 & 0.02 & & & & & & \\
\hline (14) & Expected Chance of Success & 0.31 & -0.01 & 0.02 & -0.07 & 0.03 & 0.04 & 0.01 & -0.02 & 0.36 & -0.25 & 0.26 & -0.04 & 0.04 & & & & & \\
\hline$(16)$ & Business Manufacturing & 0.01 & -0.02 & 0.00 & 0.05 & 0.00 & 0.00 & 0.03 & 0.01 & 0.05 & -0.03 & 0.01 & 0.04 & -0.02 & 0.05 & -0.03 & & & \\
\hline (17) & Services & 0.04 & 0.03 & 0.01 & -0.02 & -0.01 & 0.05 & -0.06 & -0.15 & -0.04 & 0.06 & -0.10 & -0.09 & 0.07 & 0.03 & -0.10 & -0.10 & & \\
\hline (18) & Utilities \& Regulated & 0.02 & -0.07 & 0.03 & -0.01 & 0.03 & 0.08 & -0.01 & 0.07 & 0.05 & -0.03 & 0.04 & 0.08 & -0.04 & 0.03 & 0.09 & -0.06 & -0.47 & \\
\hline (19) & Government \& NGO & -0.09 & 0.03 & -0.04 & 0.03 & -0.02 & -0.11 & 0.02 & 0.09 & -0.05 & -0.02 & 0.05 & 0.04 & -0.05 & -0.10 & 0.06 & -0.07 & -0.53 & -0.31 \\
\hline
\end{tabular}

${ }^{\mathrm{a}}$ For correlations: $>|.04| \mathrm{p}<.05 ;>|.05| \mathrm{p}<.01 ;>|.07| \mathrm{p}<.001$ 
Table 2: GEE Results for Employee Support for Change ${ }^{\mathrm{a}}$

\begin{tabular}{|c|c|c|c|c|c|c|c|c|c|c|c|c|}
\hline & (1) & & (2) & & (3) & & (4) & & (5) & & (6) & \\
\hline & b & (s.e.) & b & (s.e.) & b & (s.e.) & b & (s.e.) & b & (s.e.) & b & (s.e.) \\
\hline Intercept & 1.80 & $(0.21)^{* * *}$ & 1.81 & $(0.21)^{* * *}$ & 1.80 & $(0.21)^{* * *}$ & 1.77 & $(0.21)^{* * *}$ & 1.76 & $(0.20)^{* * *}$ & & \\
\hline Utilities \& Regulated & 0.07 & $(0.05)$ & 0.07 & $(0.05)$ & 0.07 & $(0.05)$ & 0.07 & $(0.05)$ & 0.07 & $(0.05)$ & 0.19 & $(0.08)^{*}$ \\
\hline Services & 0.15 & $(0.04)^{* * *}$ & 0.15 & $(0.04)^{* * *}$ & 0.15 & $(0.04)^{* * *}$ & 0.15 & $(0.04)^{* * *}$ & 0.15 & $(0.04)^{* * *}$ & 0.28 & $(0.08)^{* * *}$ \\
\hline Member Chg. Reference Group & -0.04 & $(0.04)$ & -0.04 & $(0.04)$ & -0.04 & $(0.04)$ & -0.04 & $(0.04)$ & -0.04 & $(0.04)$ & -0.05 & $(0.04)$ \\
\hline Expected Chance of Success & 0.06 & $(0.01)^{* * *}$ & 0.06 & $(0.01)^{* * *}$ & 0.06 & $(0.01)^{* * *}$ & 0.06 & $(0.01)^{* * *}$ & 0.06 & $(0.01)^{* * *}$ & 0.10 & $(0.01)^{* * *}$ \\
\hline Consequences for Respondent & 0.03 & $(0.01)^{* *}$ & 0.03 & $(0.01)^{* *}$ & 0.03 & $(0.01)^{* *}$ & 0.04 & $(0.01)^{* *}$ & 0.04 & $(0.01)^{* *}$ & 0.06 & $(0.01)^{* * *}$ \\
\hline Organization Size & 0.03 & $(0.06)$ & 0.03 & $(0.06)$ & 0.03 & $(0.06)$ & 0.03 & $(0.06)$ & 0.04 & $(0.06)$ & 0.10 & $(0.06)^{\dagger}$ \\
\hline Participative Change Approach & 0.17 & $(0.02)^{* * *}$ & 0.17 & $(0.02)^{* * *}$ & 0.17 & $(0.02)^{* * *}$ & 0.17 & $(0.02)^{* * *}$ & 0.17 & $(0.02)^{* * *}$ & 0.28 & $(0.02)^{* * *}$ \\
\hline Directive Change Approach & -0.18 & $(0.03)^{* * *}$ & -0.18 & $(0.03)^{* * *}$ & -0.18 & $(0.03)^{* * *}$ & -0.18 & $(0.03)^{* * *}$ & -0.17 & $(0.03)^{* * *}$ & 0.02 & $(0.02)$ \\
\hline Respondent Age & 0.00 & $(0.01)$ & 0.00 & $(0.01)$ & 0.00 & $(0.01)$ & 0.00 & $(0.01)$ & 0.00 & $(0.01)$ & 0.02 & $(0.01)^{* *}$ \\
\hline Internally-Focused Change & 0.04 & $(0.02)^{*}$ & 0.04 & $(0.02)^{*}$ & 0.04 & $(0.02)^{*}$ & 0.04 & $(0.02)^{*}$ & 0.04 & $(0.02)^{*}$ & 0.05 & $(0.02)^{* *}$ \\
\hline Market-Focused Change & -0.05 & $(0.02)^{* *}$ & -0.05 & $(0.02)^{* *}$ & -0.05 & $(0.02)^{* *}$ & -0.05 & $(0.02)^{* *}$ & -0.05 & $(0.02)^{* *}$ & -0.04 & $(0.02)^{* *}$ \\
\hline H1: CI TM - CE TM & & & -0.02 & $(0.03)$ & & & & & & & 0.04 & $(0.04)$ \\
\hline H2: CI TM - CE MM & & & & & 0.00 & $(0.08)$ & & & & & 0.01 & $(0.08)$ \\
\hline H3: CI MM - CE TM & & & & & & & 0.45 & $(0.22)^{*}$ & & & 0.59 & $(0.23)^{* *}$ \\
\hline H4: CI MM - CE MM & & & & & & & & & 0.18 & $(0.08)^{*}$ & 0.25 & $(0.08)^{* * *}$ \\
\hline Wald's & 333.48 & $* * *$ & 331.94 & $* * *$ & 333.25 & $* * *$ & 337.57 & $* * *$ & 336.04 & $* * *$ & 479.02 & $* * *$ \\
\hline
\end{tabular}

${ }^{a} \mathrm{~N}=1,795$; Subject effects: 468 . Models 1 is model with control variables only. Models 2-5 estimated with alternating reference groups for parameters corresponding to H1-H4 and 'Government \& NGO' used as reference category for industry controls. Model 6 estimated without intercept to allow for simultaneous inclusion of all categories for the parameters corresponding to H1-H4 and is used for final interpretation. 